\title{
Utilizing selective chlorination to synthesize new triangulenium dyes
}

\author{
Jesper Dahl Jensen, Niels Bisballe, Laura Kacenauskaite, Maria Storm Thomsen, Junsheng Chen, \\ Ole Hammerich and Bo W. Laursen*
}

Nano-Science Center and Department of Chemistry, University of Copenhagen, Universitetsparken 5, 2100 Copenhagen $\varnothing$ (Denmark), *E-mail: bwl@ nano.ku.dk

\begin{abstract}
Access to functionalization of new sites on the triangulenium core structure has been achieved at an early stage by chlorination with N-chlorosuccinimide (NCS), giving rise to two new triangulenium dyes ( 1 and 2). By introducing the chlorine functionalities in the acridinium precursor, positions complementary to those previously accessed by electrophilic aromatic substitution of the final dyes can be accesed. The chlorination is selective, giving only one regioisomer for both mono- and dichlorination products. For the monochlorinated acridinium compound a highly selective ring-closing reaction was discovered to generate only a single regioisomer of the cationic [4]helicene product. This discovery aspired further investigations into the mechanism of [4]helicene formation and to the first isolation of the previously proposed intermediate of the two-step $S_{N} A r$ reaction, key to all aza-bridged triangulenium and helicenium systems. A late stage functionalization of $\mathrm{DAOTA}^{+}$with NCS gave rise to a different dichlorinated compound (2). The fully ring closed chlorinated triangulenium dyes $\mathbf{1}, \mathbf{2}$ and $\mathbf{3}$ show a redshift in absorption and emission relative to the non-chlorinated analogues, while still maintaining relatively high fluorescence quantum yields of $36 \%, 26 \%$, and $41 \%$, and long fluorescence lifetimes of $15 \mathrm{~ns}, 12.5 \mathrm{~ns}$ and $16 \mathrm{~ns}$, respectively. Cyclic voltammetry shows that chlorination of the triangulenium dyes significantly lowers reduction potentials and thus allows for efficient tuning of redox and photo-redox properties.
\end{abstract}

\section{Introduction:}

Triangulenium dyes and their helicene congeners are highly stabilized carbenium systems with attractive fluorescence properties (Figure 1). ${ }^{1-3}$ High chemical and photochemical stability is key to their applications in both sensors and photocatalytic processes. ${ }^{4-9}$ The exceptionally long fluorescence lifetime of the azadioxa- and diazaoxa-triangulenium dyes $\left(\mathrm{ADOTA}^{+}\right.$and DAOTA $\left.^{+}\right)\left(\tau_{\mathrm{fl}} \approx 20 \mathrm{~ns}\right)$ enables elimination of auto fluorescence by time-gated imaging and widens the measuring range in polarization assays. ${ }^{10-13}$ The long fluorescence lifetime, emission leaning towards red and good quantum yields $(60-80 \%)$ of the $\mathrm{ADOTA}^{+}$and $\mathrm{DAOTA}^{+}$triangulenium dyes make the scaffolds obvious targets for modifications aiming at tuning the optical properties. $\mathrm{ADOTA}^{+}$and $\mathrm{DAOTA}^{+}$fluoresce at $560 \mathrm{~nm}$ and $590 \mathrm{~nm}$ respectively. ${ }^{14-15}$

Shifting the absorption and emission further to the red side of the spectrum is highly attractive for imaging applications and have been successfully achieved by replacing one of the oxygen bridges by saturated or unsaturated carbon bridges, yielding dyes with emission between $580 \mathrm{~nm}$ and $652 \mathrm{~nm} .{ }^{16-}$ ${ }^{17}$ However, in all cases these modifications come at the price of enhanced non-radiative deactivation rates resulting in somewhat reduced fluorescence quantum yields (30-60\%) and lifetimes (12-18 ns). 
These findings emphasize the significant challenges in designing red emitters with long fluorescence lifetimes and high quantum yields.

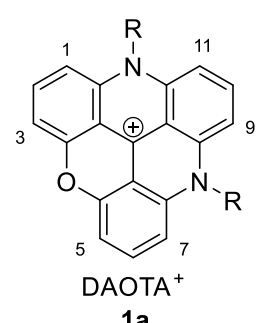<smiles>[Y7][R10]([H])([H])[H]</smiles><smiles>[R]N1c2ccccc2C2(c3c(OC)cccc3OC)c3c(OC)cccc3N([R])c3cccc1c32</smiles>

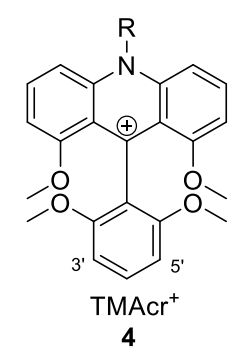

Figure 1. General structures in the triangulenium family, ADOTA $^{+}$, DAOTA ${ }^{+}$and their precursors TMAcr $^{+}$and $\mathrm{DMQA}^{+}$. For specific derivatives 1a, 3a, 4 and 7a: $\mathrm{R}=$ propyl.

In a different approach a range of functional groups were introduced into the $\mathrm{DAOTA}^{+}$system (1a) by electrophilic substitution exclusively in positions 9 and 11 (Figure 1). ${ }^{18}$ The same selectivity for the aromatic ring with the most nitrogen bridges was also found for the helicene congeners, like e.g. $\mathrm{DMQA}^{+}(\mathbf{7 a})$ reacting in the analogous 6 position (Figure 1). ${ }^{19}$ In all cases where the introduced functional groups caused a redshift this was however unfortunately accompanied by significant quenching of the fluorescence.

In this study we aim at widening the chemical diversity and tuning the optical and redox properties of $\mathrm{ADOTA}^{+}$and $\mathrm{DAOTA}^{+}$dyes by investigating chlorination, specifically targeting
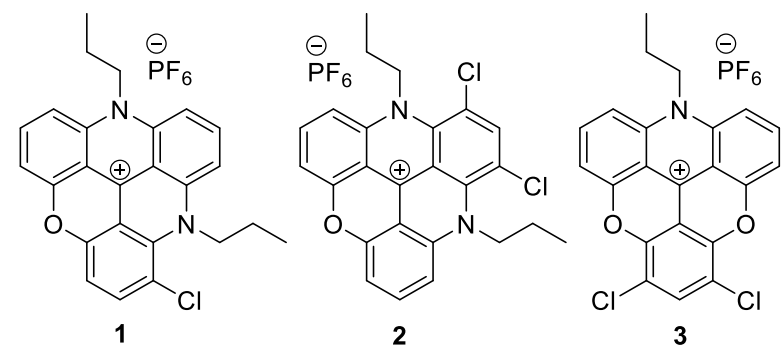

Figure 2. Molecular structure of chlorinated targets, monoand dichlorinated DAOTA ${ }^{+}(\mathbf{1}$ and $\mathbf{2})$ and dichlorinated $\mathrm{ADOTA}^{+}(\mathbf{3})$. positions of the $\mathrm{ADOTA}^{+}, \mathrm{DAOTA}^{+}$and $\mathrm{DMQA}^{+}$ chromophores not previously investigated. Tuning of the redox properties has become particularly interesting due to the high interest in applications of $\mathrm{ADOTA}^{+}, \mathrm{DAOTA}^{+}$and $\mathrm{DMQA}^{+}$in photo induced electron transfer (PET) based sensors ${ }^{20-23}$, photo catalysts, ${ }^{7-9,24-25}$ redox agents, ${ }^{26}$ and in electroluminescent systems. ${ }^{27-28}$ Specifically, we here report the synthesis, and optical and redox properties of 1-chloro-DAOTA ${ }^{+}$(1), 9,11dichloro-DAOTA ${ }^{+}(2)$ and 5,7-dichloro-ADOTA ${ }^{+}$ (3) (Figure 2).

\section{Results and Discussion:}

Synthesis. To circumvent the above-mentioned regioselectivity of the final dye systems we turned our attention to an early stage modification of the common tetramethoxy acridinium (TMAcr ${ }^{+}$, Figure 1) precursor of the $\mathrm{ADOTA}^{+}$and $\mathrm{DAOTA}^{+}$ systems. ${ }^{29}$ The readily available propyl acridinium compound 4 was mono- and di-chlorinated<smiles>CCCN1c2cccc(OC)c2C(c2c(OC)ccc(Cl)c2OC)c2c(OC)c(Cl)cc(Cl)c21</smiles><smiles>CCCN1c2cccc(OC)c2[C-](c2c(OC)cccc2OC)c2c(OC)cccc21</smiles><smiles>CCCN1c2cccc(OC)c2C(c2c(OC)ccc(Cl)c2OC)c2c(OC)cccc21</smiles>

Scheme 1. Synthetic scheme for the formation of 5 and $\mathbf{6}$. a: (1) NCS, MeCN, $55^{\circ} \mathrm{C}, 26 \mathrm{~h},(2) \mathrm{NCS}, \mathrm{MeCN}, 55^{\circ} \mathrm{C}, 4 \mathrm{~h}$, $54 \%$, b: NCS, $\mathrm{MeCN}, 55^{\circ} \mathrm{C}, 25 \mathrm{~h}, 97 \%$.

selectively in the $3^{\prime}$ and 5 ' positions of the 9dimethoxyphenyl ring of $\mathbf{4}$ by addition of $\mathrm{N}$ chlorosuccinimide (NCS) in acetonitrile (Scheme 1). This selectivity is easily understood when considering that the electron rich dimethoxyphenyl group is perpendicular to, and decoupled from, the electron deficient acridinium system. ${ }^{29-30}$ Mono chlorination was achieved using 1.06 equivalents of NCS. Reaction was carried out in a nitrogen purged sealed tube at $55^{\circ} \mathrm{C}$ for $25 \mathrm{~h} .6$ was isolated by precipitation and no further purification was needed giving an excellent yield of $97 \%$. The addition of two chlorines was achieved with almost stoichiometric control using only 2.5 equivalent of NCS. The moderate yield of 5 (54\%) is attributed to formation of the reduced $9 \mathrm{H}$-acridine with a hydride added to the central carbon. ${ }^{31}$ Based on ${ }^{1} \mathrm{H}$ NMR intensities of the crude product 
approximately $30 \%$ of the product is reduced. Careful purification of $\mathbf{5}$ is of great importance, since separation of byproducts with one or three chlorines is relatively easy at this stage, but very difficult after formation of the planar triangulenium compounds.

Ring closure of the dichlorinated acridinium 5 by heating in molten pyridine hydrochloride $(\mathrm{Pyr} \cdot \mathrm{HCl})$ gave 5,7-dichloro-ADOTA ${ }^{+}(3)$ in high yield (Scheme 2).

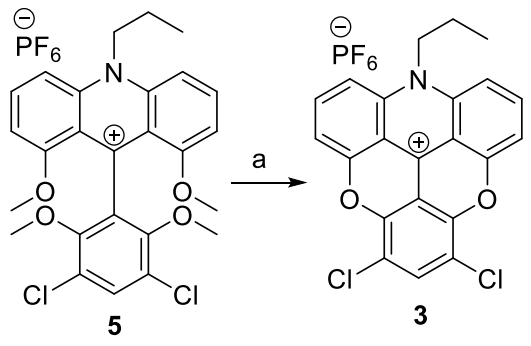

Scheme 2. Synthetic route for dichlorinated ADOTA ${ }^{+}$2. a: Pyr $\mathrm{HCl}, 200^{\circ} \mathrm{C}, 30 \mathrm{~min}, 70 \%$.

Synthesis of the DAOTA ${ }^{+}$system from the mono chlorinated acridinium $\mathbf{6}$ is performed in two steps (Scheme 3). First, the second nitrogen bridge is introduced via a double nucleophilic aromatic substitution $\left(\mathrm{S}_{\mathrm{N}} \mathrm{Ar}\right)$ with propyl amine replacing two methoxy groups yielding the [4]helicene cation 7. ${ }^{29}$ Remarkably, this reaction is highly selective and produces only $\mathbf{7}$ where the chlorine is located ortho to the newly formed nitrogen bridge (see SI for 2D NMR assignment).

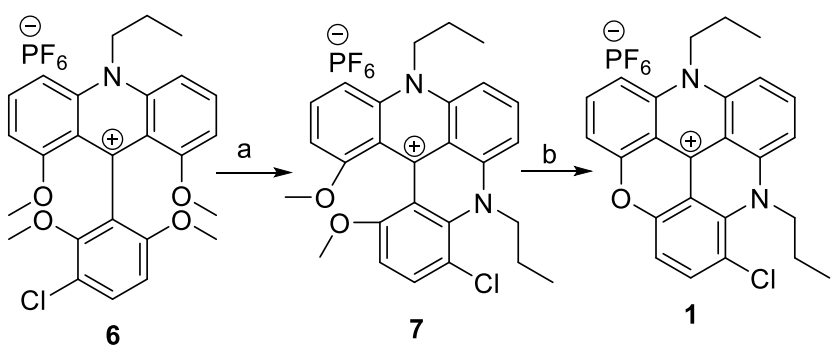

Scheme 3. Synthetic route for monochlorinated DAOTA ${ }^{+} \mathbf{1}$. a: Propylamine, $\mathrm{MeCN}, 100^{\circ} \mathrm{C}, 2 \mathrm{~h}, 39 \%$, b: $\mathrm{Pyr} \cdot \mathrm{HCl}, 220^{\circ} \mathrm{C}$, $40 \mathrm{~min}, 62 \%$.

The other possible regioisomer with chlorine para to the formed nitrogen is not observed. The moderate yield for this step is again due to the formation of the corresponding reduced product. This varies between $30-50 \%$ yield of the reduced form, based on NMR of crude samples from several reactions. Adding 7 to molten $\mathrm{Pyr} \cdot \mathrm{HCl}$ results in ring closure and $\mathrm{DAOTA}^{+}(\mathbf{1})$ is formed in $62 \%$ yield.

The reaction between 1a and NCS gave chlorination at positions 9 and 11, which comfirms the reactivty described in the literature. ${ }^{32}$ The chlorination is selective but does not occur with stoichiometric control since some trichlorination will occur prior to complete dichlorination. First 1.16 equivalents of NCS is added, and when MALDI-TOF MS shows full conversion to monochlorinated product, additional 1.04 equivalents of NCS is added to give the

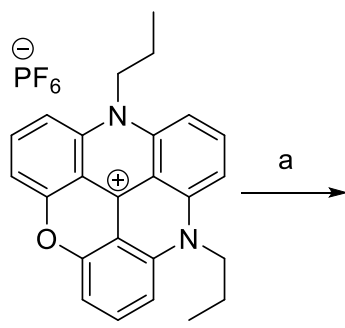

$1 \mathrm{a}$

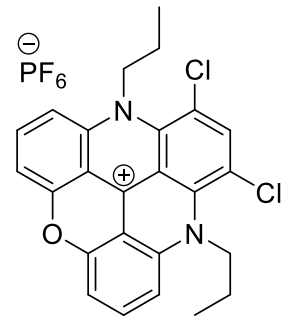

Scheme 4. Synthetic route for dichlorinated DAOTA ${ }^{+}$2. a: $\mathrm{NCS}, \mathrm{MeCN}, 55^{\circ} \mathrm{C}, 26 \mathrm{~h}, 9 \%$

dichlorinated product. The reaction gives $90 \%$ of dichlorinated DAOTA (2) in the crude sample and then some minor mono and trichlorinated impurities. As with the previous compounds purificitation of the planar triangulenium is troublesome, and repeated recrystallization in 1:1 $\mathrm{MeCN} / \mathrm{EtOH}$ was needed since the impurities tends to co-crystallize.

The observed regioselectivity in the $S_{N} A r$ reaction of $\mathbf{6}$ with propylamine yielding helicene 7 (Scheme 3 ) is intriguing since this is an absolute key step in all triangulenium and related helicenium syntheses and has not been reported previously. To investigate this reaction step further we ran the $\mathrm{S}_{\mathrm{N}} \mathrm{Ar}$ reaction at very mild conditions in the hope

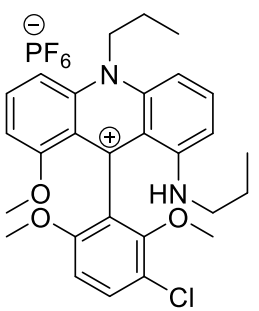

IM-1

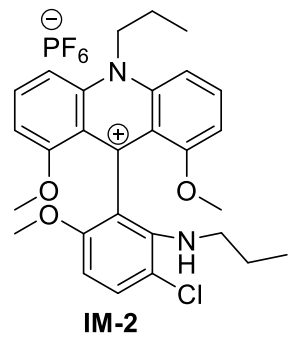

IM-2
Figure 3. The structures of two possible intermediates (IM-1 and $\mathbf{I M - 2}$ ) in the synthesis of $\mathbf{7}$. 


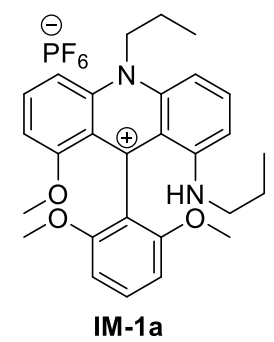

Figure 4. Molecular structure of isolated intermediate (IM1a)

that we could observe the intermediate in this twostep substitution reaction and thereby elucidate the mechanism and the origin of the regioselectivity.

The first step in the formation of $\mathbf{7}$ from $\mathbf{6}$ is a replacement of one methoxy-group by the amine nucleophile. In this case, this can in principle lead to two different products (Figure 3 ) depending if this bimolecular $\mathrm{S}_{\mathrm{N}} \mathrm{Ar}$ reaction happens on the acridinium ring system leading to IM-1 or on the dimethoxyphenyl ring leading to IM-2.

The mild substitution reaction was followed over time with MALDI-TOF recording the relative intensity for each component (Figures S30-S31). This shows that the intermediate is only present at a constant low level and the final product 7 is building up with the same rate as the starting material is consumed (Figure 5a). For comparison, we ran the same mild substitution reaction with propylamine and the non-chlorinated acridinium compound 4 (Figure S32). The results show that in this case the intermediate is building up in concentration (Figure 5b) and that the final helicene product (7a, Figure 1) is formed at a much lower rate than for the chlorinated analogue. The intermediate was isolated, and its structure identified by NMR (Figures S25-S29), as the amino-acridinium intermediate IM-1a (Figure 4). This is the first time that an intermediate of the twostep $S_{N} A r$ ring closure reactions of helicenes and triangulenium dyes has been identified and isolated. The isolated intermediate confirms the originally proposed mechanism of a bimolecular $\mathrm{S}_{\mathrm{N}} \mathrm{Ar}$ reaction controlled by the electron deficiency of the cationic reagents, ${ }^{29}$ which recently also was supported by theoretical calculations. ${ }^{33}$

Fitting the consumption of the starting acridinium compounds 4 and 6 with an exponential decay (green traces in Figure 5), matching the pseudo first order conditions, yields rate constants of $21.6 \mathrm{~h}^{-1}$ and $22.3 \mathrm{~h}^{-1}$ for $\mathbf{4}$ and $\mathbf{6}$ respectively. The reaction rates of both compounds are almost identical, which strongly indicates that the first step in the reactions is the same, and not influenced by the presence of the chlorine atom. This also implies that IM-1 must be the intermediate in the formation of the chlorinated helicene $\mathbf{7}$, and that the regioselectivity in this process originates in the second step of the reaction.

From the kinetic data for formation of the ring closed [4] helicene products $\mathbf{7}$ and $\mathbf{7 a}$ (blue traces in Figure 5) we observe a highly increased reaction rate of the chlorinated dimethoxyphenyl group in comparison to the non-chlorinated one. Thus, the chlorine atom speeds up the intramolecular ring
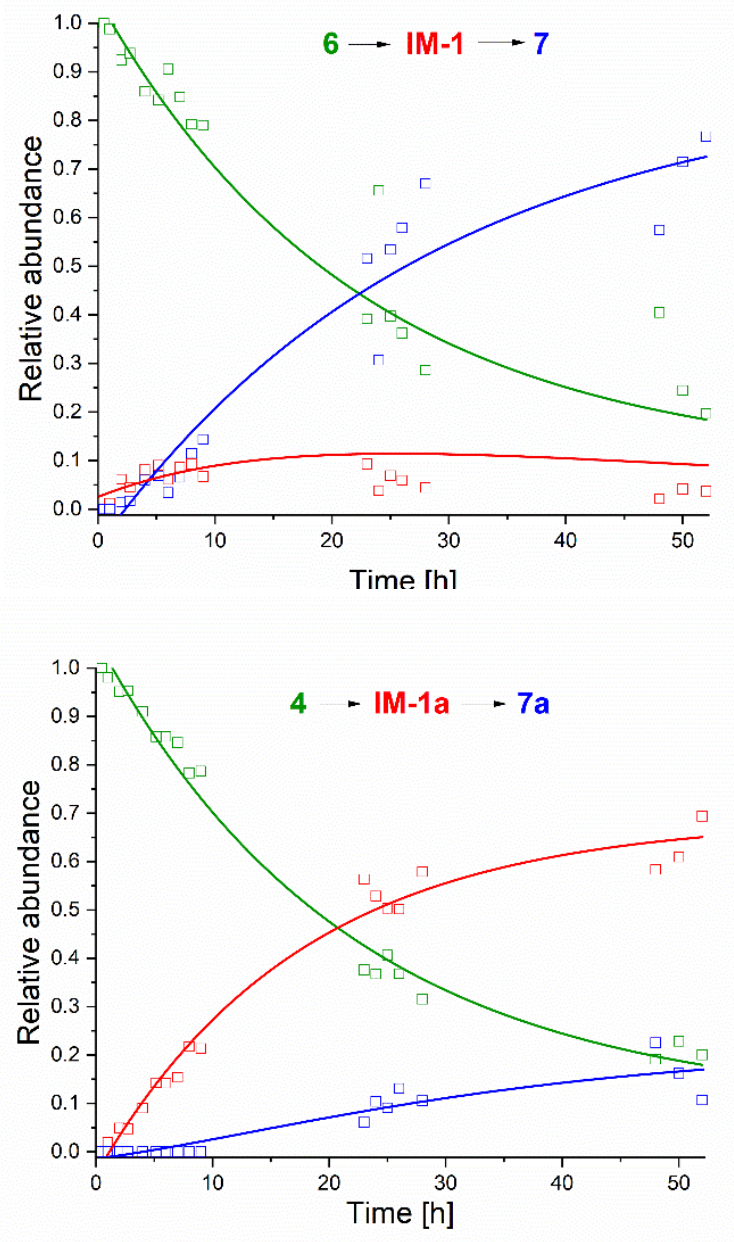

Figure 5. Kinetic experiments showing the relative abundance of the different constituents a: following the reaction of 6 with propylamine. Green $=\mathbf{6}$, red $=\mathbf{I M - 1}$ or IM-2, blue $\mathbf{=}$ 7. b: following the reaction of $\mathbf{4}$ with propylamine, Green $=4$, red $=$ IM-1a, blue $=\mathbf{7 a}$. 
closure significantly, favoring reaction ortho to chlorine leading to the selective formation of 7 . We tentatively assign the observed regio selectivity to steric effects. The chlorine atom pushes the ortho methoxy group out of the plane giving a larger area for the nucleophilic amine to attack and undergo intramolecular nucleophilic aromatic substitution.

\begin{tabular}{|l|l|l|l|l|l|l|}
\hline Compound & $\begin{array}{l}\lambda_{\mathrm{abs}} \\
{[\mathrm{nm}]}\end{array}$ & $\begin{array}{l}\lambda_{\mathrm{em}} \\
{[\mathrm{nm}]}\end{array}$ & $\Phi_{\mathrm{f}}{ }^{a}$ & $\begin{array}{l}\tau_{\mathrm{fl}} \\
{[\mathrm{ns}]}\end{array}$ & $\begin{array}{l}k_{f}{ }^{c} \\
10^{6} \\
{\left[\mathrm{~s}^{-1}\right]}\end{array}$ & $\begin{array}{c}k_{n r}{ }^{d} \\
10^{6} \\
{\left[\mathrm{~s}^{-1}\right]}\end{array}$ \\
\hline $\mathbf{1 a}$ & 558 & 576 & $0.57(0.58)^{\mathrm{b}}$ & 20.1 & 28 & 21 \\
\hline $\mathbf{1}$ & 572 & 598 & 0.36 & 14.7 & 24 & 44 \\
\hline $\mathbf{2}$ & 582 & 640 & 0.26 & 12.6 & 21 & 60 \\
\hline $\mathbf{3 a}$ & 540 & 560 & $0.64(0.69)^{\mathrm{b}}$ & 22.9 & 28 & 16 \\
\hline $\mathbf{3}$ & 555 & 574 & 0.41 & 16.1 & 26 & 37 \\
\hline
\end{tabular}

Table 1. Photophysical properties of $\mathbf{1}, \mathbf{1 a}, \mathbf{2}, \mathbf{3}$ and $\mathbf{3 a}$ in acetonitrile. ${ }^{a}$ Measured using Rhodamine $6 \mathrm{G}$ in absolute ethantol as the reference $\left(\Phi_{\mathrm{f}}=0.95\right)$ following $507 \mathrm{~nm}$ laser excitation. Refractive indices used: $\mathrm{MeCN}=1.34411$; $\mathrm{EtOH}=$ $1.36143\left(\right.$ from $\left.^{34}\right)$. ${ }^{b}$ In parentheses literature values from ${ }^{15} .{ }^{\mathrm{c}} \mathrm{k}_{f}$ $=\Phi_{\mathrm{f}} / \tau_{\mathrm{fl} l} \cdot{ }^{\mathrm{d}} k_{n r}=\left(1 / \tau_{\mathrm{fl}}\right)-k_{f}$.

Optical properties. Isolation of the aminoacridinium intermediate IM-1a (Figure 4) allows for an interesting comparison of the electronic spectra with those of the precursor $\mathbf{4}$ and the final ring closed [4] helicene 7a $\left(\mathrm{DMQA}^{+}\right)$as shown in Figure 5. [4]- and [6]-diaza-helicenes with this chromophore system have been extensively studied as dyes and photo redox reagents..$^{8-9,}{ }^{35-36}$ A key feature is the characteristic redshifted absorption and emission compared to acridinium 4. The absorption spectrum of IM-1a clearly shows that the fundamental chromophoric unit responsible for optical properties of $\mathrm{DMQA}^{+}$and related helicenes is the 1-aminoacridinium system present already in

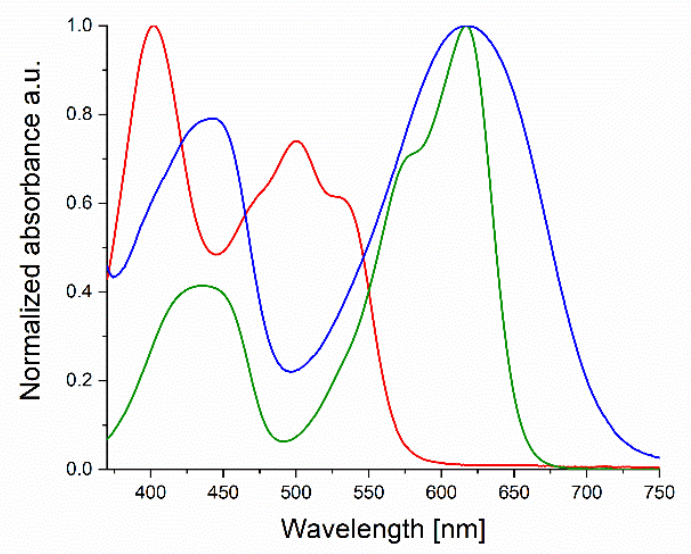

Figure 6. Normalized absorption spectra of $\mathbf{4}$ (red), $7 \mathbf{a}$ (green) and IM-1a (blue) in $\mathrm{CH}_{2} \mathrm{Cl}_{2}$.

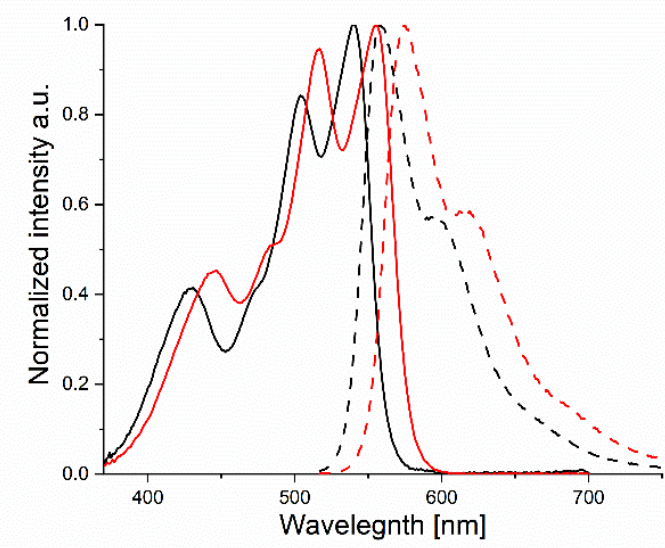

Figure 7. Normalized absorption (solid lines) and emission (dashed lines) spectra for $\mathbf{3}$ (red) and $\mathbf{3 a}$ (black) in acetonitrile.

IM-1. However, the $S_{0} \rightarrow S_{1}$ transition is broadened and no fluorescence is observed, likely due to the higher flexibility of the amino-acridinium system in IM-1a compared to $\mathbf{D M Q A}^{+}$and the likely quenching ability of 2,6-dimethoxyphenyl group.

The optical properties of the new chlorinated triangulenium dyes $\mathbf{1}, \mathbf{2}, \mathbf{3}$ and their nonchlorinated reference compounds (1a and 3a) were measured in $\mathrm{CH}_{3} \mathrm{CN}$ solutions. The absorption, excitation and emission spectra of all of the compounds can be found in Supporting Information (Figures S33-S52). The photophysical data are summarized in Table 1. Absorption and emission spectra of $\mathrm{ADOTA}^{+} \mathbf{3}$ and $\mathbf{3 a}$ are shown in Figure 7. A first observation for $\mathbf{3}$ is a redshift in absorption and emission of $15 \mathrm{~nm}$ and $14 \mathrm{~nm}$,

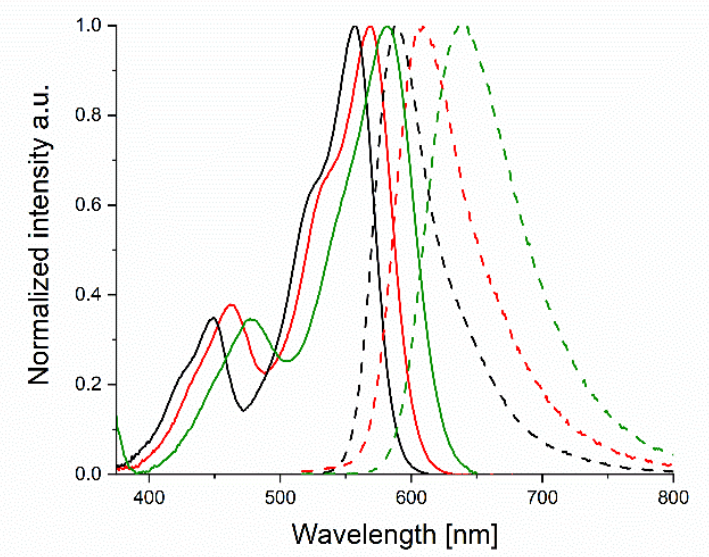

Figure 8. Normalized absorption (solid lines) and emission (dashed lines) spectra for $\mathbf{1}$ (red), $\mathbf{2}$ (green) and $\mathbf{1 a}$ (black) in acetonitrile. 
respectively, compared to 3a. The spectral shapes are also very similar indicating that chlorine does not affect the nature of the optical transitions of the dye to any large extent.

The molar absorption coefficients $\varepsilon_{\max }$ of $\mathbf{3}$ is also similar to that of 3a, $10090 \mathrm{M}^{-1} \mathrm{~cm}^{-1}$ and $9840 \mathrm{M}^{-}$ ${ }^{1} \mathrm{~cm}^{-1}$, respectively. ${ }^{37}$ This trend with general redshift of spectra and retention of absorption coefficients is also found for the mono- and dichlorinated DAOTA derivatives $\mathbf{1}$ and $\mathbf{2}$ compared to their non-chlorinated analogue 1a (Figure 8). In this case molar absorption coefficients $\varepsilon_{\max }$ are $13780 \mathrm{M}^{-1} \mathrm{~cm}^{-1}, 13515 \mathrm{M}^{-1} \mathrm{~cm}^{-}$ ${ }^{1}$ and $14800 \mathrm{M}^{-1} \mathrm{~cm}^{-1}$, respectively. ${ }^{29}$

Compared to 1a absorption and emission are redshifted by $14 \mathrm{~nm}$ and $23 \mathrm{~nm}$ for 1 and $24 \mathrm{~nm}$ and $64 \mathrm{~nm}$ for 2, respectively. Fluorescence quantum yields in acetonitrile were measured for both the chlorinated compounds and their known reference compounds. The values are listed in Table 1 and previously reported values given in parentheses. For compounds $\mathbf{1}$ and $\mathbf{3}$ the quantum yield drops by $1 / 3$ due to the chlorination whereas 2 drops by $1 / 2$, though still resulting in applicable $\Phi_{\mathrm{f}}=36 \%, 26 \%$ and $41 \%$ for $\mathbf{1}, \mathbf{2}$ and $\mathbf{3}$, respectively. All five compounds show mono exponential fluorescence decays with lifetimes $\left(\tau_{\mathrm{fl}}\right)$ between 12.5 and $23 \mathrm{~ns}$. From the fluorescence lifetimes and quantum yields, rate constants of fluorescence $\left(k_{f}\right)$ and nonradiative deactivation $\left(k_{n r}\right)$ were determined (Table 1). This analysis clearly confirms that chlorination does not affect the radiative processes but leads to an approximate doubling of the non-radiative deactivation rates, which is responsible for the reduced fluorescence quantum yields and lifetimes.

Electrochemical properties. The redox properties of the chlorinated triangulenium dyes were studied and compared to their non-chlorinated reference compounds by cyclic voltammetry (CV) and differential pulse voltammetry (DPV) in $\mathrm{CH}_{3} \mathrm{CN}$ containing $\mathrm{Bu}_{4} \mathrm{NPF}_{6}(0.1 \mathrm{M})$ as the supporting electrolyte. The cyclic voltammograms obtained at a voltage scan rate of $0.1 \mathrm{~V} \mathrm{~s}^{-1}$ are reproduced in the SI (Figures S56-S60). First, and most important, the one-electron reductions to the neutral free radicals were all reversible. The formal potentials, $E^{\circ}$, recorded by DPV are summarized in Table 2 together with the CV peak potentials, $E_{\mathrm{p}}$, observed for the further reduction of the radicals to reactive anions and for the oxidation of the cations to reactive radical dications. These latter processes were not studied further, but are briefly commented upon in the SI.

The effect of introducing one or two electron withdrawing chlorine atoms in the triangulenium systems is clearly seen in the redox potentials (Table 2). Relative to the non-chlorinated systems 1a and 3a chlorination generally lowers the reduction potentials and increases the oxidation potentials. This corresponds to lowering of both LUMO and HOMO energies and was further investigated by DFT calculations of molecular orbital energies screening all possible monochlorinated, and selected di-chlorinated, DAOTA and ADOTA derivatives (Tables S9 and S10 and Figures S61-S62). The calculated down shift of HOMO and LUMO orbital energies match well with the observed shifts in redox potentials and indicate that fine tuning of redox and photo redox properties indeed is possible by selective chlorination. An interesting feature is that introduction of two chlorines into the DAOTA ${ }^{+}$ system (as in 2) results in a reduction potential quite similar to the unsubstituted $\mathrm{ADOTA}^{+}$system thus bridging the $\sim 400 \mathrm{mV}$ two triangulenium systems. This makes it possible to have reduction potential as an $\mathrm{ADOTA}^{+}$chromophore but optical properties and substitution patterns of a DAOTA ${ }^{+}$ chromophore.

\begin{tabular}{|c|c|c|c|c|c|}
\hline Compound & $\begin{array}{c}E^{\mathrm{o}^{\prime}}\left(1^{\mathrm{st}} \mathrm{red}\right)^{\mathrm{a}} \\
\mathrm{V}\end{array}$ & $\begin{array}{c}\Delta E^{0}{ }^{\prime}\left(1^{\text {st }} \mathrm{red}\right)^{\mathrm{b}} \\
\mathrm{mV}\end{array}$ & $\begin{array}{c}E_{\mathrm{p}}\left(1^{\text {st }} \mathrm{ox}\right)^{\mathrm{c}} \\
\mathrm{V}\end{array}$ & $\begin{array}{c}\Delta E_{\mathrm{p}}\left(1^{\text {st }} \text { ox }\right)^{\mathrm{b}} \\
\mathrm{mV}\end{array}$ & $\begin{array}{c}\text { Red-Ox gap }^{\mathrm{d}} \\
\mathrm{eV}\end{array}$ \\
\hline $\mathbf{1 a}$ & $-1.360(-0.978)$ & - & $1.080(1.462)$ & - & 2.44 \\
\hline $\mathbf{1}$ & $-1.185(-0.803)$ & 175 & $1.150(1.532)$ & 70 & 2.335 \\
\hline $\mathbf{2}$ & $-0.985(-0.603)$ & 375 & $1.172(1.554)$ & 93 & 2.157 \\
\hline $\mathbf{3 a}$ & $-0.936(-0.554)$ & - & $1.438(1.820)$ & - & 2.374 \\
\hline $\mathbf{3}$ & $-0.780(-0.398)$ & 156 & $1.561(1.943)$ & 123 & 2.341 \\
\hline
\end{tabular}

Table 2. Potentials are given in $\mathrm{V}$ vs. $\mathrm{Fc} / \mathrm{Fc}^{+}$. The values in parentheses are in $\mathrm{V}$ vs. SCE obtained by addition of $0.382 \mathrm{~V} .{ }^{32}{ }^{\mathrm{a}} \mathrm{Formal}$ potential for the reversible one-electron reduction to the neutral radical. ${ }^{\mathrm{b}} \Delta E^{0}$, and $\Delta E_{\mathrm{p}}$ report change in potentials relative to the non-chlorinated references 1a and 3a. ${ }^{c}$ Peak potential(s) for the oxidation wave(s). ${ }^{\mathrm{d}}$ Approximate values based on $\mathrm{E}_{\mathrm{p}}$ and not $\mathrm{E}^{\mathrm{o}}$ ' for the oxidation process, since $\mathrm{E}^{\mathrm{o}}$ ' could not be recorded. 
Structural properties. Single crystal x-ray structures were obtained for new compounds $\mathbf{2}, \mathbf{3}$, and 7 (details given in SI S53-S55). These structures are quite similar to previously reported structures of the respective dye systems. ${ }^{29,}{ }^{38}$ For the chlorinated DAOTA ${ }^{+}$and DMQA ${ }^{+}$systems 2 and $\mathbf{7}$ the chlorine atoms are introduced in positions neighboring the propyl substituted nitrogen bridges apparently causing steric repulsing forcing the chlorine and/or propyl substituents out of plane (Figure S54). In the DFT optimized structures (Figure S63 and S64) the repulsion of chlorine and/propyl substituents are less obvious, however, here distortions of the $\pi$-systems are observed instead. This is not the case for the dichlorinated $\mathrm{ADOTA}^{+} \mathbf{3}$ which is found to be perfectly planar in both $\mathrm{x}$-ray and DFT optimized structure in agreement with the chlorine atoms being neighbors to an oxygen bridge with no steric clash (Figure S55 and S65). These structural differences may also explain the larger increase in non-radiative deactivation rate for $\mathrm{DAOTA}^{+} \mathbf{2}$ than for the fully planar $\mathrm{ADOTA}^{+} \mathbf{3}$.

\section{Conclusion:}

Electrophilic mono- and di-chlorination of the acridinium precursor $\mathbf{4}$ demonstrates an early stage functionalization strategy giving access to new substitution patterns of cationic [4]helicenes of the $\mathrm{DMQA}^{+}$family and long fluorescence lifetime $\mathrm{ADOTA}^{+}$and DAOTA ${ }^{+}$dyes. Specifically, monoand dichlorinated DAOTA $^{+} \mathbf{1}$ and $\mathbf{2}$, and dichlorinated ADOTA ${ }^{+} \mathbf{3}$ were synthesized. Their photophysical properties were characterized with moderately redshifted absorption and emission accompanied by moderate drop in fluorescence quantum yields and fluorescence lifetimes. Isolation of the amino-acridine intermediate IM-1a provides the final experimental evidence for the reaction mechanism leading to formation of $\mathrm{DMQA}^{+}$type [4]helicenes and reveals the structural origin of its unique redshifted (600-700 $\mathrm{nm})$ chromophore system.

The early stage chlorination strategy can thus be used for fine tuning of spectral properties of both cationic helicenes and long fluorescence lifetime triangulenium dyes. We also expect that this strategy will be useful for tuning of redox potentials important for photocatalysis, organic hydride donors and electrogenerated chemiluminescence applications where these cationic dye systems recently have shown promising results. ${ }^{8-9,26,28}$ Finally, the chlorinated systems are obvious starting points for coupling reactions aiming for $\pi$-system extension. ${ }^{27,39-40}$

\section{Experimental section:}

Synthetic Methods and Materials. All chemicals and solvents were purchased from commercial suppliers and used as received, except for $\mathbf{4}$ which was synthesized as described in the litterature ${ }^{29}$. The NCS was newly bought and used without further purification. Mass spectra were recorded on an ESP-MALDI-FT-ICR instrument equipped with a $7 \mathrm{~T}$ magnet (The instrument was calibrated using sodium trifluoroacetate cluster ions prior to acquiring the spectra). ${ }^{1} \mathrm{H}$ and ${ }^{13} \mathrm{C}$-NMR spectra were acquired on a Bruker $500 \mathrm{MHz}$ instrument equipped with a (non-inverse) cryoprobe. All chemical shift values in both ${ }^{1} \mathrm{H}$ and ${ }^{13} \mathrm{C}$ NMR spectra are referenced to the residual solvent peak $\left(\mathrm{CD}_{3} \mathrm{CN} \delta \mathrm{H}=1.94, \delta \mathrm{C}=118.26\right.$; ). All ${ }^{13} \mathrm{C}-\mathrm{NMR}$ are APT spectra, and uneven numbers of protons attached are referred to with + , and even numbers of protons attached are referred to with -.

Spectroscopic Methods. The solvent used for spectroscopic measurements were of HPLC grade and used as received. The UV-vis absorption spectra were recorded on a Cary $300 \mathrm{UV}$-Vis double beam spectrophotometer (Agilent Technologies, Santa Clara, USA) using pure solvent as the baseline. All spectra were recorded using $1 \mathrm{~cm}$ path length quartz cuvettes in $1 \mathrm{~nm}$ steps. The excitation spectra were recorded using a PTI QuantaMaster8075 (Horiba, Kyoto, Japan) system, using a xenon arc lamp as excitation source. The spectra were recorded at multiple wavelengths (see SI) and slits were $3 \mathrm{~nm}$ wide. The fluorescence lifetimes and emission spectra were recorded with a FluoTime 300 (PicoQuant, Berlin, Germany) system. The fluorescence decays were analyzed with the FluoFit software package. Data for the decay $\left(I_{f}(t)\right)$ were fitted by iterative reconvolution with a sum of exponentials: 


$$
I_{f}(t)=\Sigma \alpha_{i} \exp \left(-\frac{t}{\tau_{i}}\right) \quad \text { eq. } 1
$$

In eq $1, \alpha_{\mathrm{i}}$ is the amplitude and $\tau_{\mathrm{i}}$ is the fluorescence lifetime of the $i^{\text {th }}$ component. The samples were excited using a pulsed solid-state LDH-P-C-510 $\mathrm{nm}$ laser (excitation at $507 \mathrm{~nm}$ ). Fluorescence decays were recorded at $620 \mathrm{~nm}$. The instrument response function (IRF) was measured at the excitation wavelength using a dilute scattering suspension of Ludox. For all of the fluorescence measurements, the angle between the excitation and emission polarizers was set to $54.7^{\circ}$ (magic angle). All fluorescence quantum yields were determined by the relative method (eq. 2).

$$
\Phi_{X}=\Phi_{S T}\left(\frac{\operatorname{Grad}_{X}}{\operatorname{Grad}_{S T}}\right)\left(\frac{n_{X}^{2}}{n_{S T}^{2}}\right) \quad \text { eq. } 2
$$

Subscripts $\mathrm{X}$ and ST denotes test and standard respectively, $\Phi$ is the fluorescence quantum yield, Grad the gradient from the plot of integrated fluorescence intensity vs absorbance and $n$ the refractive index of the solvent. ${ }^{41}$ The samples were excited by a pulsed solid-state laser at $507 \mathrm{~nm}$, and the quantum yields were determined with respect to rhodamine $6 \mathrm{G}$ in absolute ethanol $\left(\Phi_{\mathrm{f}}=0.95\right) .{ }^{42}$ The fluorescence measurements were performed in a $10.00 \mathrm{~mm}$ path length quartz cuvette. For all quantum yield measurements, the absorbance was below 0.12 at the maximum of the lowest energy absorption band. All fluorescence spectra were corrected for the wavelength-dependent sensitivity of the detection system.

Electrochemical Methods. Cyclic voltammetry (CV) and differential pulse voltammetry (DPV) were carried out at room temperature in $\mathrm{CH}_{3} \mathrm{CN}$ containing $\mathrm{Bu}_{4} \mathrm{NPF}_{6}(0.1 \mathrm{M})$ as the supporting electrolyte using an Autolab PGSTAT12 instrument driven by the Nova 1.11 software. The working electrode was a circular glassy carbon disk $(d=3 \mathrm{~mm})$, the counter electrode was a platinum wire and the reference electrode was a silver wire immersed in the solvent-supporting electrolyte mixture and physically separated from the solution containing the substrate by a ceramic frit. The potential of the reference electrode was determined vs the ferrocene/ferrocenium $\left(\mathrm{Fc} / \mathrm{Fc}^{+}\right)$redox couple in separate experiments and the potentials were subsequently converted to V vs SCE by addition of
$0.382 \mathrm{~V} .{ }^{43}$ The $\mathrm{CV}$ voltage scan rate was $0.1 \mathrm{~V} \mathrm{~s}^{-1}$. The DPV parameters were the following: scan rate $0.01 \mathrm{~V} \mathrm{~s}^{-1}$, step potential $0.005 \mathrm{~V}$, modulation amplitude $0.025 \mathrm{~V}$, modulation time $0.05 \mathrm{~s}$ and interval time $0.5 \mathrm{~s}$. $i R$-Compensation was used in all experiments. Solutions were purged with argon saturated with $\mathrm{CH}_{3} \mathrm{CN}$ for at least ten min before the measurements were made after which a stream of argon was maintained over the solutions. The formal potentials for the reversible one-electron reductions to the neutral free radicals were determined by DPV. The other potentials were determined by $\mathrm{CV}$.

Crystallographic and computational methods are described in Supporting Information.

\section{1-Chloro-8,12-dipropyl-8,12-diaza-4-oxa triangulenium hexafluorophosphate}

In an Erlenmeyer flask $(100 \mathrm{~mL})$, pyridine hydrochloride $(10 \mathrm{~g}, 87 \mathrm{mmol})$ was heated to $220^{\circ} \mathrm{C}$ until material solidified on the inside of the flask. The material was melted back into the flask using a heat gun, and 6 (219 $\mathrm{mg}, 0.370 \mathrm{mmol})$ was added in one portion upon stirring. The mixture was stirred for $40 \mathrm{~min}$ at $220^{\circ} \mathrm{C}$. Heating was removed and the mixture was allowed to reach ambient temperature. To the mixture $\mathrm{H}_{2} \mathrm{O}(125 \mathrm{~mL})$ was added and the mixture was transferred into aqueous $\mathrm{KPF}_{6}(\mathrm{aq})(0.2 \mathrm{M}, 100 \mathrm{~mL})$, then $\mathrm{H}_{2} \mathrm{O}(75$ $\mathrm{mL}$ ) was added and it was left stirring vigorously. The precipitate was isolated by filtration, washed on the filter with $\mathrm{H}_{2} \mathrm{O}(100 \mathrm{~mL}), 0.1 \mathrm{M} \mathrm{NaOH}(\mathrm{aq})$ $(200 \mathrm{~mL}), \mathrm{H}_{2} \mathrm{O}(300 \mathrm{~mL})$ and $\mathrm{Et}_{2} \mathrm{O}(2 \times 25)$. Eluted off filter using $\mathrm{MeCN}$ and the organic solvent was then removed in vacuo. The formed solid was recrystallized in 9:1 $\mathrm{MeOH} / \mathrm{MeCN}(99 \mathrm{~mL} / \mathrm{g})$ twice. Yield: $125 \mathrm{mg}(62 \%)$.

HR-MS (ESP) found: 401.1415. Calcd. for $\mathrm{C}_{25} \mathrm{ON}_{2} \mathrm{ClH}_{22}{ }^{+}: 401.1421$

${ }^{1} \mathrm{H}$ NMR $\left(500 \mathrm{MHz}\right.$, Acetonitrile- $\left.d_{3}\right) \delta 8.26$ (t, $J=8.6$ $\mathrm{Hz}, 1 \mathrm{H}), 8.15-8.06(\mathrm{~m}, 2 \mathrm{H}), 7.62(\mathrm{~d}, J=8.9 \mathrm{~Hz}, 1 \mathrm{H})$, $7.55(\mathrm{~d}, J=8.7 \mathrm{~Hz}, 1 \mathrm{H}), 7.52(\mathrm{~d}, J=8.6 \mathrm{~Hz}, 1 \mathrm{H}), 7.32$ $(\mathrm{d}, J=8.1 \mathrm{~Hz}, 1 \mathrm{H}), 7.27(\mathrm{~d}, J=8.8 \mathrm{~Hz}, 1 \mathrm{H}), 4.75-4.68$ $(\mathrm{m}, 2 \mathrm{H}), 4.52-4.47(\mathrm{~m}, 2 \mathrm{H}), 2.12-2.08(\mathrm{~m}, 2 \mathrm{H}), 2.01$ $-1.96(\mathrm{~m}, 2 \mathrm{H}), 1.18(\mathrm{t}, J=7.4 \mathrm{~Hz}, 3 \mathrm{H}), 1.03(\mathrm{t}, J=7.4$ $\mathrm{Hz}, 3 \mathrm{H})$.

${ }^{13} \mathrm{C}$ NMR $\left(126 \mathrm{MHz}, \mathrm{CD}_{3} \mathrm{CN}\right) \delta 153.0(-), 152.8(-)$, 144.1(-), 142.8(+), 141.7(-), 141.3(-), 140.9(+), 140.76(- 
), 139.8(+), 139.0(-), 114.7(-), 113.1(-), 111.4(+), 111.1(-), 110.4(+), 109.2(+), 108.9(-), 108.3(+), $107.9(+), 55.0(-), 50.7(-), 23.0(-), 19.9(-), 11.1(+)$, $10.8(+)$.

\section{9,11-Dichloro-8,12-dipropyl-8,12-diaza-4-oxa triangulenium hexafluorophosphate (2)}

In a Pyrex tube 1a (449.3 mg, $0.878 \mathrm{mmol})$ was dissolved in MeCN (8 mL). NCS (136.0 mg, 1.02 mmol) was dissolved in MeCN (5 mL) and added to the solution of $\mathbf{1 a}$, and the mixture was left stirring over night at $55^{\circ} \mathrm{C}$. After $21 \mathrm{~h} \mathrm{NCS}(122.3$ $\mathrm{mg}, 0.916 \mathrm{mmol}$ ) dissolved in $\mathrm{MeCN}(5 \mathrm{~mL})$ was added and the reaction was left stirring for $5 \mathrm{~h}$. After a total of $26 \mathrm{~h}$, the reaction was quenched by adding the mixture to $\mathrm{KPF}_{6}(\mathrm{aq})(0.2 \mathrm{M}, 200 \mathrm{~mL})$. The precipitate was isolated by filtration and washed with $\mathrm{Et}_{2} \mathrm{O}(40 \mathrm{~mL})$. Then three consecutive recrystallizations in 1:1 EtOH/MeCN $(135 \mathrm{~mL} / \mathrm{g})$ was performed. All the mother liquors were collected and evaporated to dryness in vacuo. The formed solid was recrystallized three additional times in 1:1 EtOH/MeCN $(135 \mathrm{~mL} / \mathrm{g})$. The two recrystallized batched was collected and a last 7 th recrystallization was carried out in 1:1 $\mathrm{EtOH} / \mathrm{MeCN}(135 \mathrm{~mL} / \mathrm{g})$. The formed crystals were isolated by filtration. Yield: $43 \mathrm{mg}$ (9\%).

HR-MS (ESP) found: 435.1027 Calcd. for $\mathrm{C}_{25} \mathrm{ON}_{2} \mathrm{Cl}_{2} \mathrm{H}_{21}{ }^{+}: 435.1031$

${ }^{1} \mathrm{H}$ NMR $\left(500 \mathrm{MHz}\right.$, Acetonitrile- $\left.d_{3}\right) \delta 8.38(\mathrm{~s}, 1 \mathrm{H}), 8.16$ (t, $J=8.5 \mathrm{~Hz}, 2 \mathrm{H}), 7.67(\mathrm{~d}, J=8.9 \mathrm{~Hz}, 2 \mathrm{H}), 7.43(\mathrm{~d}, J=$ $8.2 \mathrm{~Hz}, 2 \mathrm{H}), 4.80(\mathrm{t}, J=7.9 \mathrm{~Hz}, 4 \mathrm{H}), 2.09-2.02(\mathrm{~m}$, $4 \mathrm{H}), 0.92(\mathrm{t}, J=7.3 \mathrm{~Hz}, 6 \mathrm{H})$.

${ }^{13} \mathrm{C}$ NMR (126 MHz, Acetonitrile- $\left.d_{3}\right) \delta$ 153.6(-), 145.7(+), 142.8(-), 141.7(-), 140.2(+), 134.0(-), 117.3()$, 113.8(-), 111.8(+), 110.4(+), 109.9(-), 55.8(-), 23.3(-$ ), 10.8(+).

\section{5,7-Dichloro-12-propyl-12-aza-4,8-}

dioxatriangulenium hexafluorophosphate (3) In an Erlenmeyer flask, pyridine hydrochloride (10 $\mathrm{g}, 87 \mathrm{mmol}$ ) was heated to $200^{\circ} \mathrm{C}$ until material solidified on the inside of the flask. The material was melted into the flask using a heat gun, and $\mathbf{4}$ (409.2 mg, $647.1 \mu \mathrm{mol})$ was added in one portion while stirring. The mixture was left stirring for 30 minutes, then heating was removed, and the mixture was allowed to reach ambient temperature. Water $(140 \mathrm{~mL})$ was added to the mixture which was then transferred into aqueous $\mathrm{KPF}_{6}(\mathrm{aq})(0.2 \mathrm{M}$, $150 \mathrm{~mL}$ ) and left stirring vigorously. The precipitate was isolated by filtration, washed with $\mathrm{Et}_{2} \mathrm{O}$ and then eluted off the filter using $\mathrm{MeCN}$ and concentrated in vacuo. The solid was solubilized in hot $\mathrm{MeCN}(39 \mathrm{~mL} / \mathrm{g})$ and then an equal amount of $\mathrm{EtOH}$ was added. When the solution was boiling, heating was removed and the mixture was left to crystallize, yielding dark red crystals. Yield: 245 mg $(70 \%)$.

${ }^{1} \mathrm{H}$ NMR $\left(500 \mathrm{MHz}\right.$, Acetonitrile- $\left.d_{3}\right) \delta 8.42-8.38(\mathrm{~m}$, $2 \mathrm{H}), 8.26(\mathrm{~s}, 1 \mathrm{H}), 7.94(\mathrm{~d}, J=9.0 \mathrm{~Hz}, 2 \mathrm{H}), 7.66(\mathrm{~d}, J=$ $8.1 \mathrm{~Hz}, 2 \mathrm{H}), 4.77-4.73(\mathrm{~m}, 2 \mathrm{H}), 2.08-1.99(\mathrm{~m}, 2 \mathrm{H})$, $1.19(\mathrm{t}, J=7.4 \mathrm{~Hz}, 3 \mathrm{H})$.

${ }^{13} \mathrm{C}$ NMR (126 MHz, $\left.\mathrm{CD}_{3} \mathrm{CN}\right) \delta 153.4(-), 147.7(-)$, $142.3(+), \quad 141.7(-), \quad 140.7(-), \quad 139.4(+), \quad 117.1(-)$, 112.3(+), 110.7(+), 110.2(-), 108.3(-), 51.5(-), 20.9(-), 11.2(+).

HR-MS (ESP) found: 394.0397. Calcd. for $\mathrm{C}_{22} \mathrm{NO}_{2} \mathrm{Cl}_{2} \mathrm{H}_{14}{ }^{+}: 394.0402$.

\section{9-(3,5-Dichloro-2,6-dimethoxyphenyl)-1,8- dimethoxy-10-propylacridinium hexafluorophosphate}

In a Pyrex tube 4 (1.02 g, $1.80 \mathrm{mmol})$ was dissolved in anhydrous MeCN (4 mL). Then NCS (538 mg, $4.03 \mathrm{mmol}$ ) dissolved in anhydrous $\mathrm{MeCN}$ (4.5 $\mathrm{mL}$ ) was added portion wise with a pipette. The system was flushed with $\mathrm{N}_{2}$-gas closed with a screw cap and placed at $55^{\circ} \mathrm{C}$ in an aluminium heating block for $22 \mathrm{~h}$ while stirring. Then, NCS (61.5 mg, $0.461 \mathrm{mmol})$ was dissolved in anhydrous MeCN $(1 \mathrm{~mL})$ and added to the mixture. After a total of $26 \mathrm{~h}$ the reaction was quenched by adding the mixture to $\mathrm{KPF}_{6}(\mathrm{aq})(0.2 \mathrm{M}, 200 \mathrm{~mL})$ while stirring. The red precipitate was isolated by filtration and washed with $\mathrm{Et}_{2} \mathrm{O}(200 \mathrm{~mL})$. The precipitate was recrystallized in $\mathrm{MeOH}(30 \mathrm{~mL} / \mathrm{g})$. Yield: $612 \mathrm{mg}$ (54\%).

${ }^{1} \mathrm{H}$ NMR $\left(500 \mathrm{MHz}\right.$, Acetonitrile- $\left.d_{3}\right) \delta 8.26-8.23(\mathrm{~m}$, $2 \mathrm{H}), 7.99(\mathrm{~d}, J=9.2 \mathrm{~Hz}, 2 \mathrm{H}), 7.68(\mathrm{~s}, 1 \mathrm{H}), 7.17(\mathrm{~d}, J=$ $8.0 \mathrm{~Hz}, 2 \mathrm{H}), 5.07-5.04(\mathrm{~m}, 2 \mathrm{H}), 3.64(\mathrm{~s}, 3 \mathrm{H}), 3.36$ (s, $3 \mathrm{H}), 2.30-2.21(\mathrm{~m}, 2 \mathrm{H}), 1.30(\mathrm{t}, J=7.4 \mathrm{~Hz}, 3 \mathrm{H})$.

${ }^{13} \mathrm{C}$ NMR $\left(126 \mathrm{MHz}, \mathrm{CD}_{3} \mathrm{CN}\right) \delta 160.4(-), 153.2(-)$, 142.8(-), 141.2(+), 134.6(-), 130.8(+), 123.2(-), 120.2(), 110.9(+), 108.0(+), 61.2(+), 57.9(+), 55.3(-), 22.1(-), 11.1(+). 
One quaternary carbon signal is missing.

HRMS (MALDI-TOF) found: 486.1220. Calcd. for $\mathrm{C}_{26} \mathrm{NO}_{4} \mathrm{Cl}_{2} \mathrm{H}_{26}{ }^{+}$: 486.1239

\section{9-(3-Chloro-2,6-dimethoxyphenyl)-1,8- dimethoxy-10-propylacridinium hexafluorophosphate}

In a dry Pyrex tube 4 (405 mg, $0.719 \mathrm{mmol}$ ) was dissolved in anhydrous MeCN (5 mL) flushed with $\mathrm{N}_{2}$ gas. NCS (102 mg, $0.764 \mathrm{mmol}$ ) was dissolved in anhydrous $\mathrm{MeCN}(2 \mathrm{~mL})$ and added portion wise to the Pyrex tube. The system was then flushed with $\mathrm{N}_{2}$ gas, closed with a screw cap and left stirring at $55^{\circ} \mathrm{C}$ in an aluminium heating block. After $25 \mathrm{~h}$ the reaction was complete. The mixture was cooled to room temperature and added portion wise via pipette to $\mathrm{KPF}_{6}(\mathrm{aq})(0.2 \mathrm{M}, 350 \mathrm{~mL})$ while stirring. The fine red precipitate was isolated by filtration and washed with $\mathrm{Et}_{2} \mathrm{O}(20 \mathrm{~mL})$. No further purification was needed. Yield: $415 \mathrm{mg}$ $(97 \%)$.

${ }^{1} \mathrm{H}$ NMR (500 MHz, Acetonitrile- $\left.d_{3}\right) \delta 8.24-8.20(\mathrm{~m}$, $2 \mathrm{H}), 7.94(\mathrm{~d}, J=9.2 \mathrm{~Hz}, 2 \mathrm{H}), 7.51(\mathrm{~d}, J=8.9 \mathrm{~Hz}, 1 \mathrm{H})$, $7.13(\mathrm{~d}, J=8.0 \mathrm{~Hz}, 2 \mathrm{H}), 6.89(\mathrm{~d}, J=8.9 \mathrm{~Hz}, 1 \mathrm{H}), 5.05$ $-5.01(\mathrm{~m}, 2 \mathrm{H}), 3.60(\mathrm{~s}, 3 \mathrm{H}), 3.58(\mathrm{~s}, 6 \mathrm{H}), 3.28(\mathrm{~s}, 3 \mathrm{H})$, $2.27-2.19(\mathrm{~m}, 2 \mathrm{H}), 1.28(\mathrm{t}, J=7.4 \mathrm{~Hz}, 3 \mathrm{H})$.

${ }^{13} \mathrm{C}$ NMR (126 MHz, CD $\left.3 \mathrm{CN}\right) \delta 161.0(-), 156.4(-)$, 155.5(-), 151.5(-), 142.7(-), 141.0(+), 130.5(+), 127.99(), 120.5(-), 119.4(-), 110.6(+), 107.9(+), 107.7(+), 60.9(+), 57.8(+), 57.0(+), 55.0(-), 22.1(-), 11.11(+).

HRMS (MALDI-TOF) found: 452.1622. Calcd. for $\mathrm{C}_{26} \mathrm{H}_{27} \mathrm{ClNO}_{4}{ }^{+}$: 452.1629 .

\section{4-Chloro-1,13-dimethoxy-5,9-}

dipropylquinolino[2,3,4- $k l]$ acridinium hexafluorophosphate

To a Pyrex tube 5 (398 mg, $0.665 \mathrm{mmol}$ ) was dissolved in anhydrous $\mathrm{MeCN}(2.2 \mathrm{~mL})$. Propylamine $(0,55 \mathrm{~mL}, 7.7 \mathrm{mmol})$ was added via syringe, and the system was flushed with $\mathrm{N}_{2}$-gas. The Pyrex tube was sealed with a screw cap and placed in an aluminium heating block at $100^{\circ} \mathrm{C}$ for $2 \mathrm{~h}$ while stirring. Upon cooling the reaction mixture was added dropwise to $\mathrm{KPF}_{6}(\mathrm{aq})(0.2 \mathrm{M}$, $200 \mathrm{~mL}$ ). The precipitate was isolated by filtration and washed with $\mathrm{Et}_{2} \mathrm{O}(100 \mathrm{~mL})$. The precipitate was washed off the filter with $\mathrm{MeCN}$ and reprecipitated in $\mathrm{Et}_{2} \mathrm{O}(200 \mathrm{ml})$. The reprecipitated solid was collected by filtration and washed off filter with DCM and concentrated in vacuo. The formed solid was then recrystallized in 8:2 iPrOH/MeCN (49 mL/g). Yield: 153 mg (39\%).

${ }^{1} \mathrm{H}$ NMR (500 MHz, Acetonitrile- $\left.d_{3}\right) \delta 8.18(\mathrm{t}, J=8.4$ $\mathrm{Hz}, 1 \mathrm{H}), 8.02-7.97(\mathrm{~m}, 1 \mathrm{H}), 7.85(\mathrm{~d}, J=8.9 \mathrm{~Hz}, 1 \mathrm{H})$, $7.67(\mathrm{~d}, J=8.7 \mathrm{~Hz}, 1 \mathrm{H}), 7.61(\mathrm{~d}, 2 \mathrm{H}), 6.99$ (d, $J=8.0$ $\mathrm{Hz}, 1 \mathrm{H}), 6.94(\mathrm{~d}, J=9.0 \mathrm{~Hz}, 1 \mathrm{H}), 5.08(\mathrm{dt}, J=14.2,7.0$ $\mathrm{Hz}, 1 \mathrm{H}), 4.79-4.70(\mathrm{~m}, 1 \mathrm{H}), 4.61-4.50(\mathrm{~m}, 2 \mathrm{H}), 3.78$ (s, 3H), 3.69 (s, 3H), $2.12-2.04(\mathrm{~m}, 2 \mathrm{H}), 1.66-1.49$ $(\mathrm{m}, 2 \mathrm{H}), 1.21(\mathrm{t}, J=7.4 \mathrm{~Hz}, 3 \mathrm{H}), 0.50(\mathrm{t}, J=7.3 \mathrm{~Hz}$, $3 \mathrm{H})$.

${ }^{13} \mathrm{C}$ NMR (126 MHz, $\left.\mathrm{CD}_{3} \mathrm{CN}\right) \delta 160.8(-), 158.2(-)$, 144.0(-), 143.1(-), 142.6(-), 141.7(-), 139.5(-), 139.2(+), 139.0(+), 137.6(+), 123.0(-), 119.6(-), 115.9(-), 115.1(), 109.9(+), 108.8(+), 107.3(+), 107.0(+), 104.3(+), 58.5(-), 56.87(+), 56.79(+), 52.9(-), 22.9(-), 21.1(-), 11.24(+), 11.23(+).

HR-MS (ESP) found: 447.1832. Calcd. for $\mathrm{C}_{27} \mathrm{~N}_{2} \mathrm{O}_{2} \mathrm{ClH}_{27}{ }^{+}$: 447.1839 .

\section{9-(2,6-Dimethoxyphenyl)-1-methoxy-8- propylamino-10-propylacridinium} hexafluorophosphate (IM-1a): 4 (201 mg, 0.357 $\mathrm{mmol})$ was dissolved in acetonitrile $(1.2 \mathrm{~mL})$ in a Pyrex reaction tube. Propylamine $(0.30 \mathrm{~mL}, 3.65$ $\mathrm{mmol}$ ) was added to the red solution, resulting in some decoloration. The reaction tube was sealed with a screw cap and placed in a heating block at $35^{\circ} \mathrm{C}$. Reaction progress was monitored by MALDI-TOF. The solution darkened with increasing reaction time. After 4.8 days around 50 $\%$ conversion of the starting material was observed by MALDI-TOF, with no progress for the past 3 days. The reaction was removed from the heating block and allowed to cool to room temperature. The dark green reaction solution was poured into $\mathrm{Et}_{2} \mathrm{O}$ under vigorous stirring and the resulting precipitate was isolated by filtration. After thorough washing with $\mathrm{Et}_{2} \mathrm{O}$, the precipitate was eluted off the filter with DCM. The solvent was subsequently evaporated under reduced pressure at $35^{\circ} \mathrm{C}$ and the product was purified by flash column chromatography (DCM-MeOH, 98:2) to give the product as a dark green solid $(65 \mathrm{mg}, 31 \%)$. The product is not completely pure, but sufficient for structural assignment and observing optical properties. 
${ }^{1} \mathrm{H}$ NMR $\left(500 \mathrm{MHz}\right.$, Acetonitrile- $\left.d_{3}\right) \delta 8.07(\mathrm{dd}, J=9.1$, $8.0 \mathrm{~Hz}, 1 \mathrm{H}), 7.99-7.93(\mathrm{~m}, 1 \mathrm{H}), 7.75(\mathrm{~d}, J=9.1 \mathrm{~Hz}$, $1 \mathrm{H}), 7.63(\mathrm{t}, J=8.5 \mathrm{~Hz}, 1 \mathrm{H}), 7.27(\mathrm{~d}, J=8.8 \mathrm{~Hz}, 1 \mathrm{H})$, $6.98(\mathrm{~d}, J=8.0 \mathrm{~Hz}, 1 \mathrm{H}), 6.91(\mathrm{~d}, J=8.5 \mathrm{~Hz}, 2 \mathrm{H}), 6.60$ $(\mathrm{d}, J=8.4 \mathrm{~Hz}, 1 \mathrm{H}), 5.84$ (s br, 1H), $4.87-4.74(\mathrm{~m}, 2 \mathrm{H})$, $3.62(\mathrm{~s}, 6 \mathrm{H}), 3.47(\mathrm{~s}, 3 \mathrm{H}), 2.92(\mathrm{td}, J=7.0,4.5 \mathrm{~Hz}, 2 \mathrm{H})$, 2.17-2.10 (m, 2H), 1.33-1.13 (m, 5H), $0.77(\mathrm{t}, J=7.4$ $\mathrm{Hz}, 3 \mathrm{H})$.

${ }^{13} \mathrm{C}$ NMR (126 MHz, Acetonitrile- $\left.d_{3}\right) \delta 161.2(-)$, $157.2(-), 155.3(-), 152.3(-), 143.0(-), 142.4(-)$, $142.0(+), 139.8(+), 133.2(+), 118.2(-)^{*}, 116.9(-$ ), $109.9(+), 106.8(+), 106.1(+), 105.1(+), 103.1$ $(+), 57.8(+), 57.0(+), 54.4(-), 46.8(-), 22.2(-)$, $21.4(-), 12.0(+), 11.1(+) .{ }^{*}$ Two signals missing. Seen as cross peaks in HMBC.

HRMS (ESP): Calcd. for $\mathrm{C}_{28} \mathrm{H}_{33} \mathrm{~N}_{2} \mathrm{O}_{3}{ }^{+}\left[\mathrm{M}^{+}\right]$: 445.2491. Found: 445.2493.

\section{Conflicts of interest}

The authors declare the following competing financial interests: Bo W. Laursen is associated with the company KU-dyes, which produces and sells fluorescent dyes (including triangulenium dyes).

\section{Acknowledgements}

The work was supported by the Danish Council of Independent Research (DFF-6111-00483).

\section{References:}

1. Laursen, B. W.; Krebs, F. C., Synthesis of a triazatriangulenium salt. Angew. Chem. Int. Ed. 2000, 39 (19), 3432-3434.

2. Laursen, B. W.; Krebs, F. C.; Nielsen, M. F.; Bechgaard, K.; Christensen, J. B.; Harrit, N., 2,6,10-

Tris(dialkylamino)trioxatriangulenium ions. Synthesis, structure, and properties of exceptionally stable carbenium ions. J. Am. Chem. Soc. 1998, 120 (47), 12255-12263.

$3 . \quad B o s s o n$, J.; Gouin, J.; Lacour, J., Cationic triangulenes and helicenes: synthesis, chemical stability, optical properties and extended applications of these unusual dyes. Chem Soc Rev 2014, 43 (8), 2824-40.

$4 . \quad$ Sørensen, T. J.; Rosenberg, M.; Frankær, C. G.; Laursen, B. W., An Optical pH Sensor Based on Diazaoxatriangulenium and
Isopropyl-Bridged Diazatriangulenium Covalently Bound in a Composite Sol-Gel. Advanced Materials Technologies 2018, $O$ (0), 1800561. 5. Rosenberg, M.; Laursen, B. W.; Frankær, C. G.; Sørensen, T. J., A Fluorescence Intensity Ratiometric Fiber Optics-Based Chemical Sensor for Monitoring pH. Advanced Materials Technologies 2018, 3 (12), 1800205.

$6 . \quad$ Dalfen, I.; Dmitriev, R. I.; Holst, G.; Klimant, I.; Borisov, S. M., Background-Free Fluorescence-Decay-Time Sensing and Imaging of $\mathrm{pH}$ with Highly Photostable

Diazaoxotriangulenium Dyes. Anal Chem 2019, 91 (1), 808-816.

$7 . \quad$ Gueret, R.; Poulard, L.; Oshinowo, M.; Chauvin, J.; Dahmane, M.; Dupeyre, G.; Lainé, P. P.; Fortage, J.; Collomb, M.-N., Challenging the [Ru(bpy)3]2+ Photosensitizer with a Triazatriangulenium Robust Organic Dye for Visible-Light-Driven Hydrogen Production in Water. ACS Catalysis 2018, 8 (5), 3792-3802.

8. Hargenrader, G. N.; Weerasooriya, R. B.; Ilic, S.; Niklas, J.; Poluektov, O. G.; Glusac, K. D., Photoregeneration of Biomimetic Nicotinamide Adenine Dinucleotide Analogues via a Dye-Sensitized Approach. ACS Applied Energy Materials 2018.

9. Mei, L.; Veleta, J. M.; Gianetti, T. L., Helical Carbenium Ion: A Versatile Organic Photoredox Catalyst for Red-Light-Mediated Reactions. J. Am. Chem. Soc. 2020, 142 (28), 12056-12061.

10. Maliwal, B. P.; Fudala, R.; Raut, S.; Kokate, R.; Sørensen, T. J.; Laursen, B. W.; Gryczynski, Z.; Gryczynski, I., Long-Lived Bright Red Emitting Azaoxa-Triangulenium Fluorophores. PLOS ONE 2013, 8 (5), e63043. $11 . \quad$ Rich, R. M.; Stankowska, D. L.; Maliwal, B. P.; Sorensen, T. J.; Laursen, B. W.; Krishnamoorthy, R. R.; Gryczynski, Z.; Borejdo, J.; Gryczynski, I.; Fudala, R., Elimination of autofluorescence background from fluorescence tissue images by use of time-gated detection and the AzaDiOxaTriAngulenium (ADOTA) fluorophore. Anal Bioanal Chem 2013, 405 (6), 2065-2075.

12. Sørensen, T. J.; Thyrhaug, E.; Szabelski, M.; Luchowski, R.; Gryczynski, I.; Gryczynski, Z.; Laursen, B. W., Azadioxatriangulenium: a long fluorescence 
lifetime fluorophore for large biomolecule binding assay. Methods and Applications in Fluorescence 2013, 1 (2), 025001.

13. Laursen, B. W.; Bogh, S. A.; Sørensen, T. J., Chapter Twelve - Long fluorescence lifetime triangulenium dyes in imaging and fluorescence polarization assay. In Methods in Enzymology, Chenoweth, D. M., Ed. Academic Press: 2020; Vol. 640, pp 249-265.

\section{$14 . \quad$ Thyrhaug, E.; Sørensen, T. J.;} Gryczynski, I.; Gryczynski, Z.; Laursen, B. W., Polarization and Symmetry of Electronic Transitions in Long Fluorescence Lifetime Triangulenium Dyes. J. Phys. Chem. A 2013, 117 (10), 2160-2168.

15. Bogh, S. A.; Simmermacher, M.; Westberg, M.; Bregnhøj, M.; Rosenberg, M.; De Vico, L.; Veiga, M.; Laursen, B. W.; Ogilby, P. R.; Sauer, S. P. A.; Sørensen, T. J., Azadioxatriangulenium and Diazaoxatriangulenium: Quantum Yields and Fundamental Photophysical Properties. ACS Omega 2017, 2 (1), 193-203.

16. Rosenberg, M.; Rostgaard, K. R.; Liao, Z.; Madsen, A. O.; Martinez, K. L.; Vosch, T.; Laursen, B. W., Design, synthesis, and time-gated cell imaging of carbon-bridged triangulenium dyes with long fluorescence lifetime and red emission. Chem Sci 2018, 9 (12), 3122-3130. $17 . \quad$ Rosenberg, M.; Santella, M.; Bogh, S. A.; Muñoz, A. V.; Andersen, H. O. B.; Hammerich, O.; Bora, I.; Lincke, K.; Laursen, B. W., Extended Triangulenium lons: Syntheses and Characterization of Benzo-Bridged Dioxa- and Diazatriangulenium Dyes. The Journal of Organic Chemistry 2019, 84 (5), 2556-2567.

$18 . \quad$ Delgado, I. H.; Pascal, S.; Besnard, C.; Voci, S.; Bouffier, L.; Sojic, N.; Lacour, J., CFunctionalized Cationic Diazaoxatriangulenes: Late-Stage Synthesis and Tuning of Physicochemical Properties. Chemistry 2018, 0 (0).

19. Delgado, I. H.; Pascal, S.; Wallabregue, A.; Duwald, R.; Besnard, C.; Guenee, L.; Nancoz, C.; Vauthey, E.; Tovar, R. C.; Lunkley, J. L.; Muller, G.; Lacour, J., Functionalized cationic 4 helicenes with unique tuning of absorption, fluorescence and chiroptical properties up to the far-red range. Chemical Science 2016, 7 (7), 4685-4693.
20. Rosenberg, M.; Junker, A. K. R.; Sorensen, T. J.; Laursen, B. W., Fluorescence $\mathrm{pH}$ Probes Based on Photoinduced Electron Transfer Quenching of Long Fluorescence Lifetime Triangulenium Dyes. Chemphotochem 2019, 3 (5), 233-242.

21. Lewis, B. W.; Bisballe, N.; Santella, M.; Summers, P. A.; Vannier, J.-B.; Kuimova, M. K.; Laursen, B. W.; Vilar, R., Assessing The Key Photophysical Properties of Triangulenium Dyes for DNA Binding by Alteration of the Fluorescent Core. Chemistry - A European Journal 2021, 27 (7), 2523-2536.

22. Shivalingam, A.; Izquierdo, M. A.; Marois, A. L.; Vysniauskas, A.; Suhling, K.; Kuimova, M. K.; Vilar, R., The interactions between a small molecule and G-quadruplexes are visualized by fluorescence lifetime imaging microscopy. Nature communications 2015, 6 , 8178.

23. Frankær, C. G.; Rosenberg, M.; Santella, M.; Hussain, K. J.; Laursen, B. W.; Sørensen, T. J., Tuning the pKa of a $\mathrm{pH}$ Responsive Fluorophore and the Conse-quences for Calibration of Optical Sensors based on a Single Fluorophore but Multiple Receptors. ACS Sensors 2019, 4 (3), 764-773.

24. Shaikh, A. C.; Moutet, J.; Veleta, J. M.; Hossain, M. M.; Bloch, J.; Astashkin, A. V.; Gianetti, T. L., Persistent, highly localized, and tunable [4] helicene radicals. Chemical Science 2020.

$25 . \quad$ Mei, L.; Moutet, J.; Stull, S. M.; Gianetti, T. L., Synthesis of CF3-Containing Spirocyclic Indolines via a Red-Light-Mediated Trifluoromethylation/Dearomatization Cascade. The Journal of Organic Chemistry 2021, 86 (15), 10640-10653.

26. Ilic, S.; Pandey Kadel, U.; Basdogan, Y.; Keith, J. A.; Glusac, K. D., Thermodynamic Hydricities of Biomimetic Organic Hydride Donors. J. Am. Chem. Soc. 2018, 140 (13), 45694579.

27. Voci, S.; Duwald, R.; Grass, S.; Hayne, D. J.; Bouffier, L.; Francis, P. S.; Lacour, J.; Sojic, N., Self-enhanced multicolor electrochemiluminescence by competitive electron-transfer processes. Chemical Science 2020, 11 (17), 4508-4515. 
28. Adam, C.; Wallabregue, A.; Li, H. D.; Gouin, J.; Vanel, R.; Grass, S.; Bosson, J.; Bouffier, L.; Lacour, J.; Sojic, N., Electrogenerated Chemiluminescence of Cationic Triangulene Dyes: Crucial Influence of the Core Heteroatoms (vol 21, pg 19243, 2015). Chem. Eur. J. 2019, 25 (30), 7402-7402.

$29 . \quad$ Laursen, B. W.; Krebs, F. C., Synthesis, structure, and properties of azatriangulenium salts. Chem. Eur. J. 2001, 7 (8), 1773-1783.

30. Laleu, B.; Herse, C.; Laursen, B. W.; Bernardinelli, G.; Lacour, J., Bent structure and dynamic stereochemistry of chiral acridinium cations. J. Org. Chem. 2003, 68 (16), 6304-6308.

31. Nicolas, C.; Herse, C.; Lacour, J., Catalytic aerobic photooxidation of primary benzylic amines using hindered acridinium salts. Tetrahedron Lett. 2005, 46 (27), 4605-4608. $32 . \quad$ Delgado, I. H.; Pascal, S.; Besnard, C.; Voci, S.; Bouffier, L.; Sojic, N.; Lacour, J., CFunctionalized Cationic Diazaoxatriangulenes: Late-Stage Synthesis and Tuning of Physicochemical Properties. Chemistry - A European Journal 2018, 24 (40), 10186-10195. 33. Labrador, G. M.; Besnard, C.; Bürgi, T.; Poblador-Bahamonde, A. I.; Bosson, J.; Lacour, J., Stereochemical significance of $\mathrm{O}$ to $\mathrm{N}$ atom interchanges within cationic helicenes: experimental and computational evidence of near racemization to remarkable enantiospecificity. Chemical Science 2019, 10 (29), 7059-7067.

34. Murov, S. L.; Carmichael, I.; Hug, G. L., Handbook of Photochemistry. 2nd ed.; Marcel Dekker: 1993.

35. $\quad$ Babic, A.; Pascal, S.; Duwald, R.; Moreau, D.; Lacour, J.; Allemann, E., [4] HeliceneSqualene Fluorescent Nanoassemblies for Specific Targeting of Mitochondria in Live-Cell Imaging. Adv. Funct. Mater. 2017, 27 (33), 1701839-n/a. 36. Torricelli, F.; Bosson, J.; Besnard, C.; Chekini, M.; Burgi, T.; Lacour, J., Modular synthesis, orthogonal post-functionalization, absorption, and chiroptical properties of cationic [6]helicenes. Angew Chem Int Ed Eng/ 2013, 52 (6), 1796-800.

37. Bogh, S. A.; Simmermacher, M.; Westberg, M.; Bregnhoj, M.; Rosenberg, M.; De Vico, L.; Veiga, M.; Laursen, B. W.; Ogilby, P. R.; Sauer, S. P. A.; Sørensen, T. J., Azadioxatriangulenium and Diazaoxatriangulenium: Quantum Yields and Fundamental Photophysical Properties. Acs Omega 2017, 2 (1), 193-203.

38. Herse, C.; Bas, D.; Krebs, F. C.; Burgi, T.; Weber, J.; Wesolowski, T.; Laursen, B. W.; Lacour, J., A highly configurationally stable [4] heterohelicenium cation. Angew. Chem. Int. Ed. 2003, 42 (27), 3162-3166.

39. Krebs, F. C.; Spanggaard, H.; Rozlosnik, N.; Larsen, N. B.; Jørgensen, M., Synthesis, Properties, and Langmuir-Blodgett Film Studies of an Ionic Dye Terminated Rigid Conducting Oligomer. Langmuir 2003, 19 (19), 7873-7880.

$40 . \quad$ Hammersh $\varnothing$ j, P.; Sørensen, T. J.; Han, B.-H.; Laursen, B. W., Base-Assisted One-Pot Synthesis of $\mathrm{N}, \mathrm{N}^{\prime}, \mathrm{N}^{\prime \prime}$-Triaryltriazatriangulenium Dyes: Enhanced Fluorescence Efficiency by Steric Constraints. The Journal of Organic Chemistry 2012.

$41 . \quad$ Resch-Genger, U.; Rurack, K., Determination of the photoluminescence quantum yield of dilute dye solutions (IUPAC Technical Report). Pure Appl. Chem. 2013, 85 (10), 2005-2013.

42. Magde, D.; Wong, R.; Seybold, P. G., Fluorescence Quantum Yields and Their Relation to Lifetimes of Rhodamine $6 \mathrm{G}$ and Fluorescein in Nine Solvents: Improved Absolute Standards for Quantum Yields 1 . Photochemistry and Photobiology 2002, 75 (4), 327-334.

43. $\quad$ Aranzaes, J. R.; Daniel, M. C.; Astruc, D., Metallocenes as references for the determination of redox potentials by cyclic voltammetry - Permethylated iron and cobalt sandwich complexes, inhibition by polyamine dendrimers, and the role of hydroxy-containing ferrocenes. Canadian Journal of Chemistry 2006, 84 (2), 288-299. 